\title{
Population parameters and bio-exploitation status of Indian Mackerel (Rastrelliger kanagurta Cuvier, 1816) in Mayalibit Bay, Raja Ampat, Indonesia
}

\author{
DIAN OKTAVIANI ${ }^{\boldsymbol{\gamma}}$, SETIYA TRIHARYUNI, DUTO NUGROHO \\ Center for Fisheries Research, Agency for Marine and Fisheries Research and Human Resource, Ministry of Marine Affairs and Fisheries. Gedung \\ Balitbang KP. II, Jl. Pasir Putih II, Ancol Timur, Jakarta Utara 14430, Jakarta, Indonesia. Tel.: +62-21-64700928 Fax.: +62-21-64700929, "email: \\ dianoktavianni@gmail.com, dianoktavianni@gmail.com.
}

Manuscript received: 26 September 2019. Revision accepted: 15 November 2019.

\begin{abstract}
Oktaviani D, Triharyuni S, Nugroho D. Population parameters and bio-exploitation status of Indian mackerel (Rastrelliger kanagurta Cuvier, 1816) in Mayalibit Bay, Raja Ampat, Indonesia. Biodiversitas 20: 3545-3552. A small-scale fishery in Mayalibit bay, Raja Ampat is one among rare fisheries systems existing in Indonesia. The area already designated as a conservation zone, and Indian mackerel is the main target species by fishers. This species plays a significant role in supplying domestic food. Fisher harvest with a small wooden boat, no engine, one-night fishing using Petro-lamp, and harvested with a scoop net. Monthly based biological observations on population parameters were carried out from March 2011 to April 2012. The result shows that the fish landed with size from 10.0 to 27.0 $\mathrm{cm}$, and $70 \%$ of the sample is within $21-23 \mathrm{~cm}$ length. Monthly length-weight relationships indicate $\mathrm{b}$ value statistically equal to 3 . The average unsexed Fulton condition factor index is $1.516 \pm 0.13$ and illustrates the fishes were in suitable environmental conditions. The growth rate $(\mathrm{K})$ is estimated at 0.97 , while length infinity $(\mathrm{L} \infty)$ is $28.4 \mathrm{~cm}$. To evaluate the fishery, repeated observation of fishing in Mayalibit bay conducted in 2016. A productivity and susceptibility analysis was applied to predict its bio-exploitation status, and the results indicate that harvest levels are relatively at low-to-medium risk. Nevertheless, most of the fish caught in the bay by traditional knowledge consisted of mature cohorts while limited desk study to semi-industrial fishing targetted the same species in surrounding waters indicated that a significant proportion of undersize or immature individuals are in their landing. This phenomenon suggested that managing the existing local knowledge could significantly contribute to maintaining sustainable spawning stocks in the conservation zone.
\end{abstract}

Keywords: Exploitation, Lema, Mayalibit-Bay, population-parameters, Rastrelliger kanagurta

\section{INTRODUCTION}

These Indian mackerel (Rastrelliger kanagurta) is one of the species of small pelagic groups which widespread in tropical seas of Indo-west Pacific from South Africa, Seychelles, and the Red Sea east to Indonesia to northern Australia to Ryukyu Islands including Mediterranean Sea (Fisher and Whitehead 1974; Collette and Nauen 1983). In Indonesia, harvesting mainly by small pelagic seiner, and become one of the common species that utilized for decades. Several studies were published elsewhere, and most of this fishery in western and central part of Indonesian waters indicates that the harvest rates tend at higher than optimum levels such as in northern Sulawesi (Faizah et al. 2017), Malacca strait (Hariati et al. 2015), and Java Sea (Triharyuni et al. 2015). To obtain status and trend of this similar fisheries, a study based on data and information in the Eastern part of Indonesia was carried out in northern part of West Papua with a sampling site at Mayalibit bay, Raja Ampat.

Raja Ampat islands located in the bird's head region of West Papua province. Administratively the district became autonomous regency in 2003. The Mayalibit bay with an area of 53,100 hectares located in a specific part of the Islands. The bay is relatively small, semi-enclosed with the depth ranging from 2 to $25 \mathrm{~m}$, and designated as a regional marine conservation area (KKPD) through local government regulation No. 27 of 2008., Coastal population of around 3,190 inhabitants. To sustain their livelihood, fishing activities play a significant role as the primary source of domestic food consumption. The small-scale fisheries targeted these typical species, and ethnoichthyological studies indicate that there are three species of Rastrelliger, i.e., R. brachysoma, R. faughni, and $R$. kanagurta as dominant species in the area (Oktaviani et al. 2012).

Several types of fisheries exist in the area, one of the target species is Indian mackerel (Rastrelliger kanagurta), which locally named "lema." Traditional scoop fishing with light is the only permitted method to catch the fish. Studies on population parameters, biological sensitivity and its susceptibility to the exploitation of this species were limited in the surrounding remote areas of Indonesia. The analysis was performed mainly based on the data collected in 2011-2012. Several snapshot observations on biological aspects from 2013-2018 in the area and its adjacent waters were compiled through desk study, and the result was comprehensively used as a comparison in this analysis.

Simple classical tropical fisheries assessments were performed based on biological sensitivity and susceptibility as vulnerability indicators of this species. The results are expected to evaluate consequences on human impact 
between traditional fishing in restricted and semicommercial fisheries the open access areas to the same target species.

\section{MATERIALS AND METHODS}

\section{Study area}

The study was carried out through field observations in a marine protected area of Raja Ampat District, West Papua Province, Indonesia. Sampling conducted in two main villages around Mayalibit Bay, which is Warsambin $\left(00^{\circ} 16^{\prime} 04.08\right.$ 'S and $130^{\circ} 55^{\prime} 10.088^{\prime \prime}$ E) and Lopintol $\left(00^{\circ} 18 ' 53.82^{\prime \prime}\right.$ S-13053'28.50” E) (Figure 1). The bay surrounded by coral reefs associated with oceanic waters of the western Pacific Ocean. The seas have ecological significance, and part of the coral triangle zone, which strongly connected to the neritic coastal, reef condition, and small islands are scattered surrounding this area (McKenna et al. 2002; Agostini et al. 2012). Local ecological knowledge on lunar and tidal cycles are the major physical parameters supporting the local community's daily fishing activity.

\section{Data collection}

Data were collected from March 2011 to February 2012 from local fishing activities. A small-scale fisher with a dug boat of less than 1 Gross Tonnage (GT) (UU 7/2016) using a scoop net and kerosene lamp is the main sampling gear during observation. Since limited historical data is available, secondary annual landing data at the district level were used to describe the dynamics of fisheries in the area. Population parameters were calculated based on 4055 length-frequency measurements, which collected during the moonless period. Fork length (FL) was measured to the nearest centimeter and weight $(\mathrm{W})$ to nearest gram.

\section{Data analysis}

The length frequency of each sample was measured within a length interval of $0.5 \mathrm{~cm}$. Samples ranging from 10 to $27 \mathrm{~cm}$. The frequency distributions computed by formula (Jin et al. 2015):

$$
\mathrm{F}_{i}=\mathrm{n}_{i} / \mathrm{N} * 100
$$

Where: $\mathrm{F}_{i}=$ the frequency for a particular interval; $\mathrm{n}_{i}=$ number of specimens in each range; $\mathrm{N}=$ total number of specimen measures.

\section{Length-weight}

The length-weight relationship was computed unsexed and between males and females (smallest to largest size). The length-weight relationship (LWR) is a cubic relationship between length (L) and weight (W), represented a power curve equation (1) (King, 2007):

$$
\mathrm{W}=\mathrm{aL}^{\mathrm{b}}
$$

Where:

$\mathrm{W}=$ body weight in grams $(\mathrm{g})$;

$\mathrm{L}=$ length in $\mathrm{cm}(\mathrm{FL}$

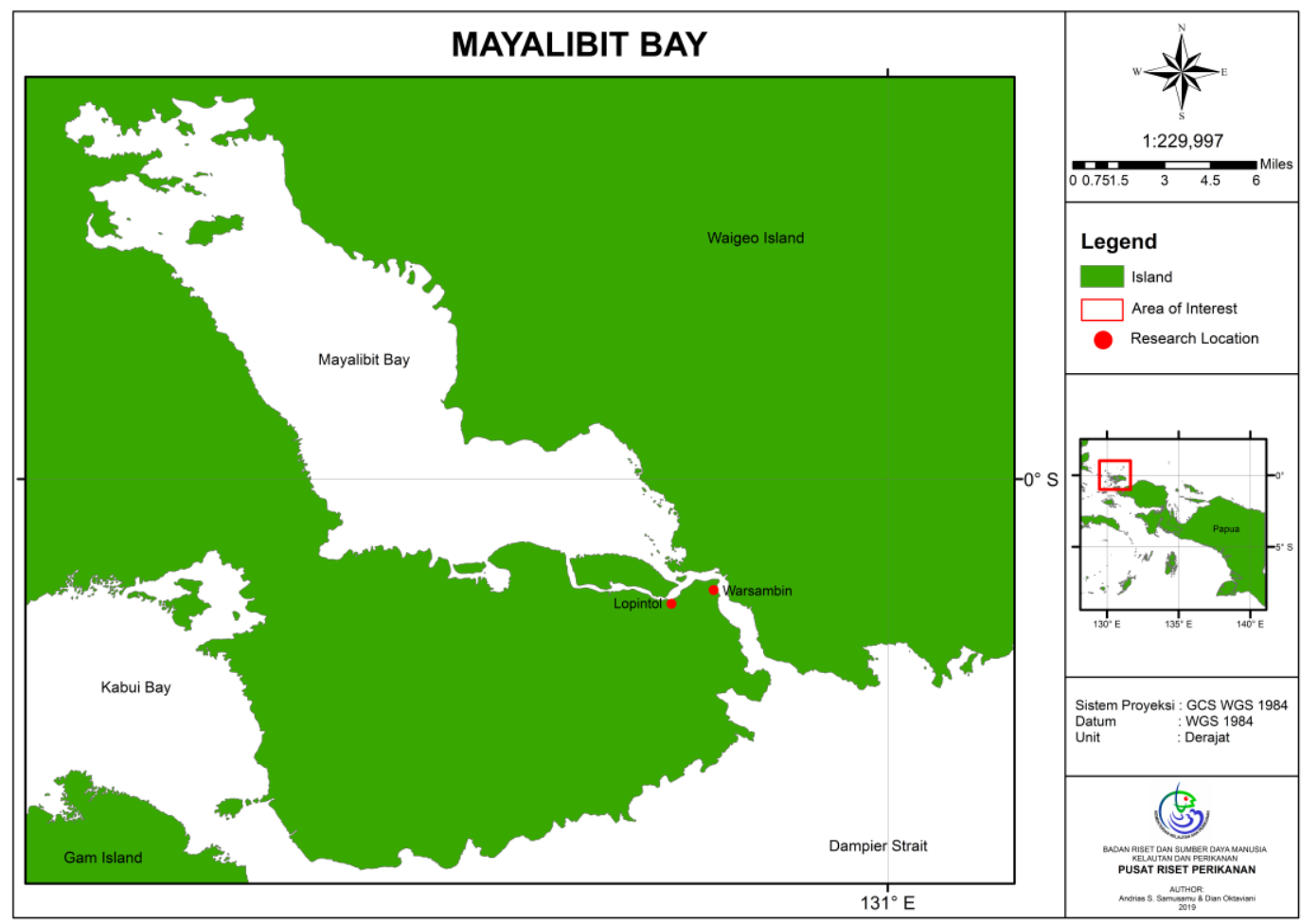

Figure 1. Waigeo Island, Sub-district of Mayalibit Bay, Raja Ampat District, West Papua Province, Indonesia 
The student's t-test was used to determine whether the parameter $b$ is significantly different from the expected or theoretical value of 3 or isometric. Parameters "a" and "b" are constants based on the measured length-weight relationship.

Fulton's condition factor $\left(K_{n}\right)$ is an indicator of the health condition of individual fish to illustrate the mechanism of reproduction and survival (Stevenson and Woods, 2006), and it is also used to describe conditions fish at one time in a relatively similar location (Nash et al. 2006). The index is the ratio of fish weight to rank length of 3 following the equation by Fulton (1904), cited in Froese (2006) as follows:

$$
\mathrm{K}=100 * \mathrm{~W} / \mathrm{L}^{3}
$$

$$
\begin{aligned}
& \text { Where: } \\
& \mathrm{K}=\text { Fulton's condition factor; } \\
& \mathrm{W}=\text { weight of fish }(\mathrm{g}) ; \\
& \mathrm{L}=\text { length of fish }(\mathrm{cm}) ; \\
& 100=\text { scaling factor to close to } 1
\end{aligned}
$$

\section{Population parameters}

Population parameters were analyze based on monthly length-frequency data and computed by using modal progression analyses. The year class determined by applying the Battacharya method. Length-based age determination methods of simple tropical fish stock assessment were used in this analysis (King 2007). Growth rates $(\mathrm{K})$ were estimated by following linear equation that correlates between length increments by unit of time $\left(\frac{\Delta L}{\Delta t}\right)$ and estimated length at time $t\left(L_{t}\right)$ :

$$
\left(\frac{\Delta L}{\Delta t}\right)=K^{*}\left(L_{m s}-L_{t}\right)
$$

The estimated time at $\mathrm{L}=0$ or $\left(\mathrm{t}_{0}\right)$ was determined by applying the equation of King (2007):

$$
\log \left(-\mathrm{t}_{0}\right)=0,3922-0,2752 \log \left(\mathrm{L}_{\infty}\right)-1.038 \log (\mathrm{K})
$$

The growth parameter $(\mathrm{K})$ was calculated from the von Bertalanffy growth equation:

$$
L_{t}=L_{\infty}\left(1-e^{-K\left(t^{-} t_{0}\right)}\right.
$$

\section{Status}

An evaluation carried out based on the scoring system under the matrix; then, all scores were graphically plotted. The vulnerability index determined through a scatter plot of productivity (axis) and susceptibility (ordinate) by using an equation of:

$$
\mathrm{v}=\sqrt{(p-3)^{2}+(s-1)^{2}}
$$

Where:

$\mathrm{v}=$ vulnerability index;

$\mathrm{p}=$ score of productivity;

$\mathrm{s}=$ score of susceptibility

\section{RESULTS AND DISCUSSION}

\section{Fisher behavior}

Previous research indicates that Raja Ampat Islands are one of the crystalline waters of the bird's head region in West Papua, Indonesia, and there were high concentrations of marine species (www.conservation.org). Fisher behavior that exists for decades with relatively low technological creeps is the primary knowledge that would sustain their harvest system. Studies on the ethnozoology, reproductive biology and sustainable use of this species with emphasizes of traditional ecological knowledge were previously explored by Oktaviani et al. (2012; 2014). Fishing apparatus consisted of small-scale fishing craft with a scoop net as the primary fishing gear, and a kerosene lamp is the source of light to aggregate (Figure 2). Fishing operations are conducted mainly during the dark period (Oktaviani 2014).

\section{Population parameters}

\section{Length frequency distribution}

A total number of 3712 specimens were measured, the average length is $20.5+3.73 \mathrm{~cm}$ and weight $143.8+52.2 \mathrm{~g}$ The monthly length-frequency distribution showed that $R$. kanagurta are ranging between 19.0 and $27.0 \mathrm{~cm}$, except in March, April, December 2011, January and February 2012 when some specimens with length of less than $12 \mathrm{~cm}$ entering the fisheries (Figure 3). A previous study on the estimation length of first maturity $\left(\mathrm{L}_{\mathrm{m}}\right)$ found at $19.55 \mathrm{~cm}$ (Oktaviani et al. 2014). This $\mathrm{L}_{\mathrm{m}}$ indicates that most of the fish caught are at sizes bigger than a length at first maturity. A small cohort of immature $(<12 \mathrm{~cm})$ contributed approximately at less than $4 \%$ of the annual landing.

The occurrence of immature groups of fish probably indicates the recruitment stocks also occur in the bay, and it could not be avoided by the fishers that used a small mesh size. Interview with fishers explained that immature size was landed as an incidental catch during the particular season of the year. It happened when multi-cohort of fish shoals migrates into the bay, and there were some difficulties in dissociating the young cohort.

\section{Length-weight relationship}

Length-weight relationships are essential parameters to allow the conversion of growth in-length based on growth in-weight based, and to estimate the condition factor of a particular species (Moutupoulos and Stregiou 2002). The specimens range were separated between males and females. The male specimen ranges from 9.2-25.5 cm FL, female range from 10.1-26.9 cm FL. The results of the Ttest show that all the value of $t_{\text {calc }}<t_{\text {table, which means that }}$ all monthly $\mathrm{b}$ values were significantly different with 3 (p<0.05), indicating that $R$ kanagurta has an allometric form (Table 1). Most of the fish are allometric positive except March and October for males, September, and November for males and females. The negative allometric probably related to most of the samples were in translucent stage (Oktaviani et al. 2014) indicating the fish were at a period of spawning stage. 


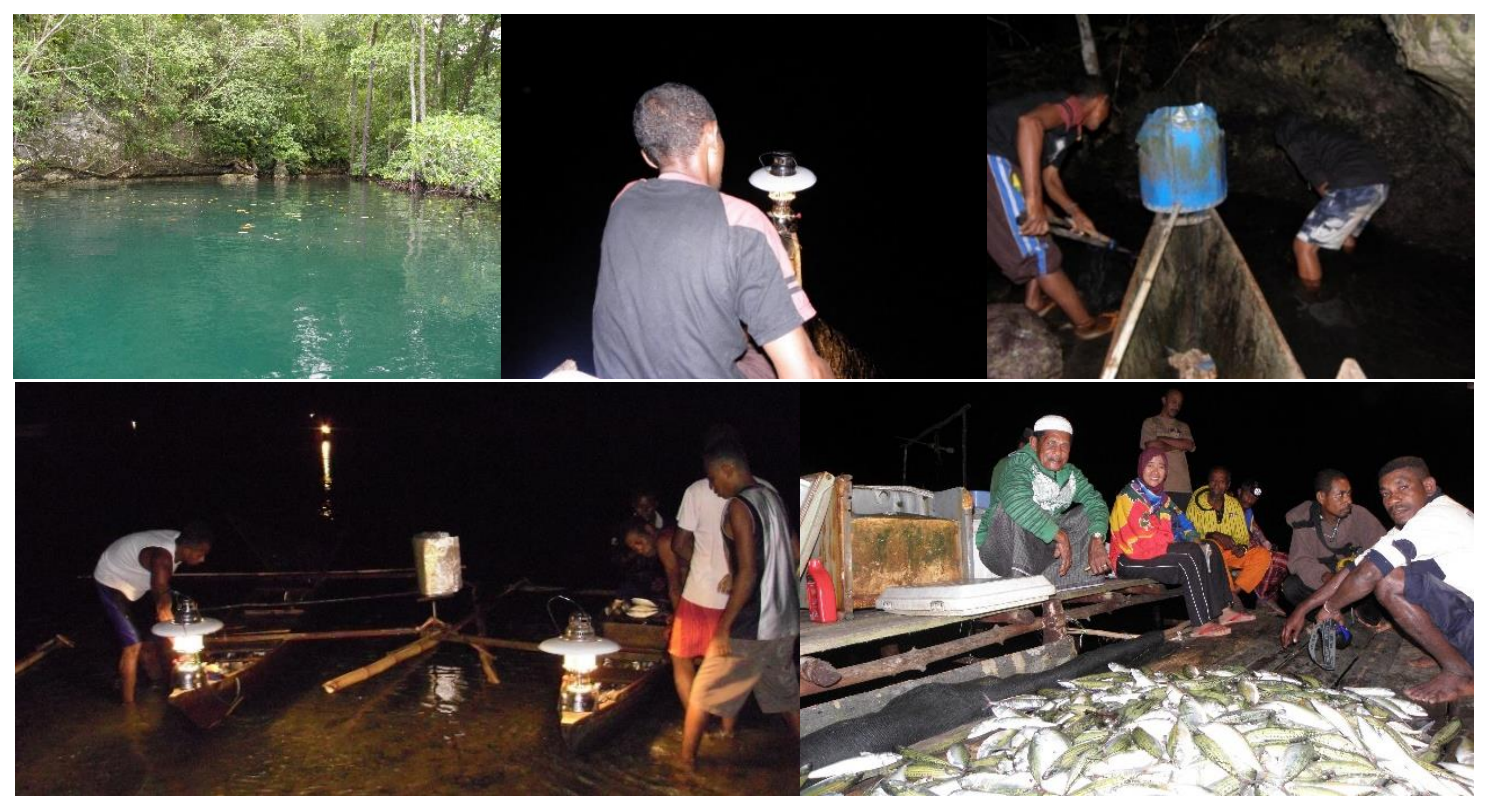

Figure 2. Fishing area, activities, and its gear, (A) fishing area; (B) leaving ashore small dugout-boat no engine with kerosene lamp; (C) herding the target fish; (D) landing, (E) trading
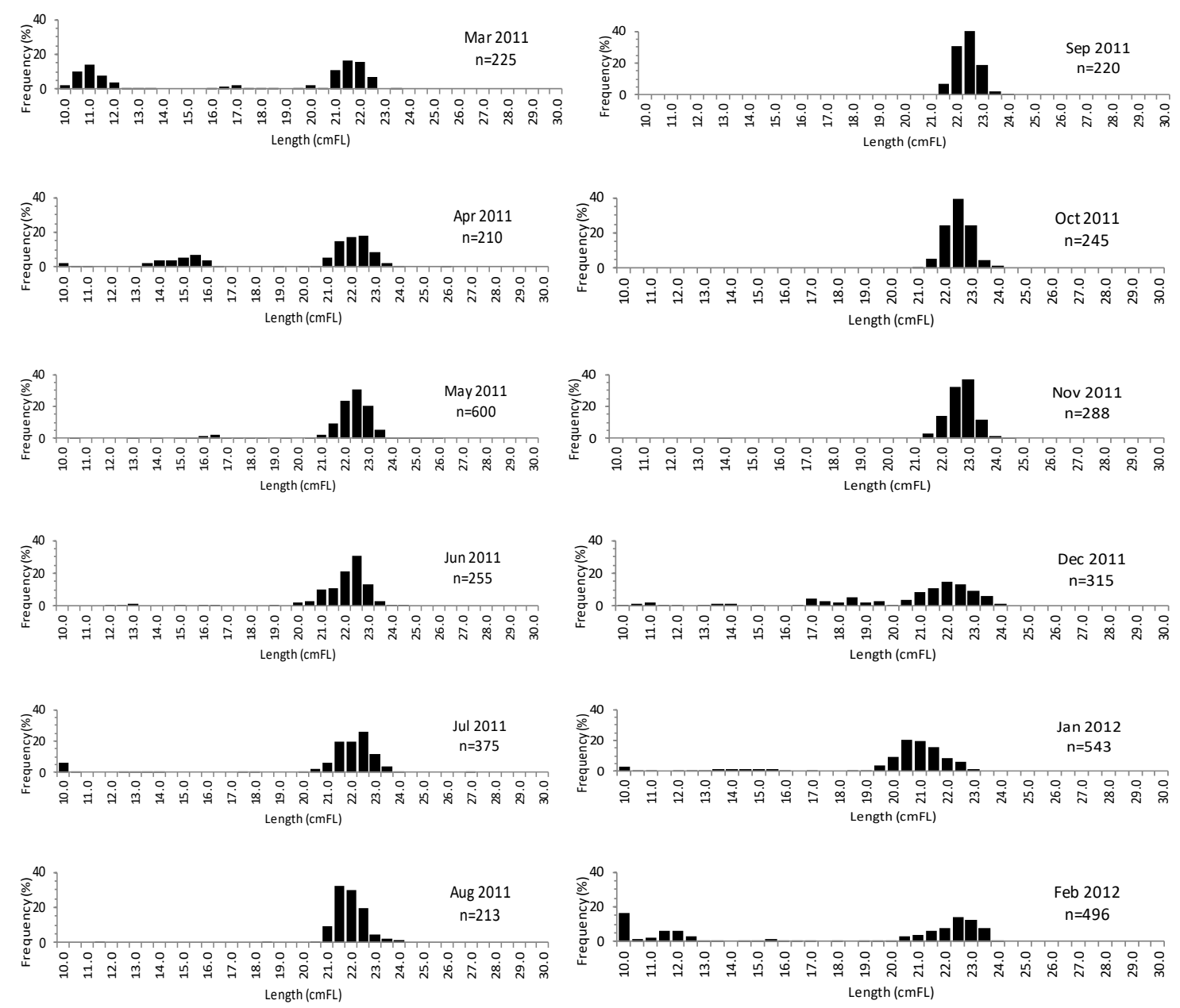

Figure 3. Length frequency distribution of R. kanagurta, March 2011-February 2012, Mayalibit bay, Indonesia 


\section{Fulton's Condition Factor}

Two main parameters in fish biology are a lengthweight relationship (LWR) and Fulton's condition factor (K). LWR can be used to estimate its weight from each length, length class, or length-frequency distribution in a population (Petrakis and Stergiou 1995). Condition factor $\left(\mathrm{K}_{\mathrm{n})}\right.$ represents the status of the well-being of individuals in the fish population, and the relative condition factor could provide an essential measure of different life stages and valuable for the management of fishery resources in a particular ecosystem (Nair et al. 2015). The observation showed that $\mathrm{Kn}$ proportionally increased with a range of Kn from 0.9 to 1.9 within the length from 9.2 to $26.9 \mathrm{~cm}$ (Figure 4).

This study showed that a monthly Kn fluctuated both for males and females. The low $\mathrm{Kn}$ values for males occurred during March and August for both sexes, a low $\mathrm{Kn}$ in August could be related to early spawning season (Oktaviani et al. 2014). The average Kn of male specimens 1.51 (0.90-1.96) and female 1.49 (1.01-1.90) (Figure 5). The Kn values each month are significantly different $(\mathrm{P}<$ 0.05 (Table 2). Therefore, the average monthly $\mathrm{Kn}$ could be influenced by maturity stages, which are $50-100 \%$ translucent gonad sample were mostly found in September to November (Oktaviani et al. 2014). However, LeCren (1951) in Froese (2006) points out that understanding the variability of condition factors is one of complex biological characteristics of fish, i.e. it can be caused by differences in season or gonad development between specimens, slightly different from body shape between population, or different mean length in respective sample.

\section{Growth parameter}

Applying the growth estimates through common on tropical fish stock assessment von Bertalanffy growth equation with parameters of $\mathrm{K}, \mathrm{t}_{\mathrm{o}}$ and $\mathrm{L} \infty$, then growth curve was plotted. A Modal progression analysis within the range of measured specimens was used to estimate $\mathrm{K}$ and L $\infty$. These parameters omit time, and fish size would be inline to describe real fish growth and development for further yield calculation in the simulation model. The result shows that estimates $\mathrm{K}$ and $\mathrm{L} \infty$ were 0.97 and $28.4 \mathrm{~cm}$, with a coefficient determinant of $\mathrm{R}^{2}=0.54$ (Figure 6).

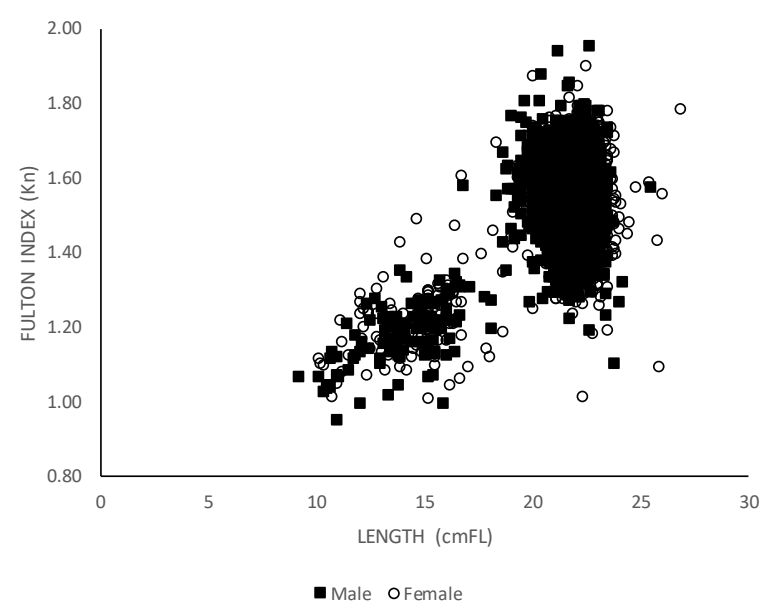

Figure 4. Scatter plot of Length (cm, FL) and Fulton condition factor $(\mathrm{Kn})$

Table 1. Length-weight relationship by sex

\begin{tabular}{|c|c|c|c|c|c|c|c|c|}
\hline \multirow{2}{*}{ Period } & \multirow{2}{*}{ Sex } & \multirow[b]{2}{*}{$\mathbf{n}$} & \multicolumn{2}{|c|}{ Length-weight } & \multirow[b]{2}{*}{$\mathbf{a}$} & \multirow{2}{*}{ b } & \multirow{2}{*}{$P$-value } & \multirow{2}{*}{$\mathbf{C}$} \\
\hline & & & Length (cm) & Weight (g) & & & & \\
\hline \multirow[t]{2}{*}{ Mar-11 } & M & 62 & $16.8-22.2$ & $75.0-170.0$ & 0.0194 & 2.9182 & $1.06246 \mathrm{E}-17$ & A- \\
\hline & $\mathrm{F}$ & 49 & $16.4-22.4$ & $55.0-185.0$ & 0.0057 & 3.3214 & $1.31154 \mathrm{E}-23$ & $\mathrm{~A}+$ \\
\hline \multirow[t]{2}{*}{ Apr } & M & 91 & $13.1-23.4$ & $26.0-206.4$ & 0.0019 & 3.6717 & $1.00563 \mathrm{E}-79$ & $\mathrm{~A}+$ \\
\hline & $\mathrm{F}$ & 100 & $13.0-26.0$ & $24.9-273.7$ & 0.0031 & 3.5157 & $1.61595 \mathrm{E}-89$ & $\mathrm{~A}+$ \\
\hline \multirow[t]{2}{*}{ May } & M & 304 & $13.6-25.5$ & $28.8-261.5$ & 0.0038 & 3.4459 & $1.716 \mathrm{E}-195$ & $\mathrm{~A}+$ \\
\hline & $\mathrm{F}$ & 295 & $10.2-25.8$ & $11.7-260.5$ & 0.0043 & 3.4039 & $6.0218 \mathrm{E}-228$ & $\mathrm{~A}+$ \\
\hline \multirow[t]{2}{*}{ June } & $\mathrm{M}$ & 132 & $12.5-24.2$ & $23.8-197.7$ & 0.0074 & 3.2356 & $2.02 \mathrm{E}-86$ & $\mathrm{~A}+$ \\
\hline & $\mathrm{F}$ & 120 & $12.0-23.8$ & $21.8-208.3$ & 0.0062 & 3.2831 & $9.26833 \mathrm{E}-86$ & $\mathrm{~A}+$ \\
\hline \multirow[t]{2}{*}{ Jul } & M & 161 & $12.9-23.2$ & 24.0-199.1 & 0.0043 & 3.4142 & $9.8623 \mathrm{E}-101$ & $\mathrm{~A}+$ \\
\hline & $\mathrm{F}$ & 186 & $10.1-26.9$ & $11.5-347.4$ & 0.0032 & 3.5144 & $2.2586 \mathrm{E}-158$ & $\mathrm{~A}+$ \\
\hline \multirow[t]{2}{*}{ Aug } & M & 82 & $18.1-24.0$ & $75.6-180.0$ & 0.0065 & 3.2462 & 8.60377E-29 & $\mathrm{A}+$ \\
\hline & $\mathrm{F}$ & 131 & $11.1-23.8$ & $16.3-210.0$ & 0.0079 & 3.1811 & $9.87055 \mathrm{E}-87$ & $\mathrm{~A}+$ \\
\hline \multirow[t]{2}{*}{ Sep } & M & 116 & $21.1-23.1$ & $137.9-225.8$ & 0.1072 & 2.3715 & 8.32205E-14 & A- \\
\hline & $\mathrm{F}$ & 104 & $21.2-23.8$ & $142.5-231.2$ & 0.5875 & 1.8381 & $1.48438 \mathrm{E}-09$ & A- \\
\hline \multirow[t]{2}{*}{ Oct } & M & 120 & $21.0-23.3$ & $140.3-202.5$ & 0.0562 & 2.5855 & $5.37553 \mathrm{E}-15$ & A- \\
\hline & $\mathrm{F}$ & 124 & $21.2-23.7$ & $138.1-231.3$ & 0.0126 & 3.0704 & $2.85268 \mathrm{E}-21$ & $\mathrm{~A}+$ \\
\hline \multirow[t]{2}{*}{ Nov } & M & 115 & $21.3-23.5$ & $147.9-219.7$ & 0.0161 & 2.9387 & $1.64897 \mathrm{E}-24$ & A- \\
\hline & $\mathrm{F}$ & 120 & $21.5-24.5$ & $155.0-225.4$ & 0.0691 & 2.5772 & $5.17745 \mathrm{E}-16$ & A- \\
\hline \multirow[t]{2}{*}{ Dec } & M & 134 & $9.2-23.7$ & $8.3-223.6$ & 0.0032 & 3.5081 & $6.1217 \mathrm{E}-141$ & $\mathrm{~A}+$ \\
\hline & $\mathrm{F}$ & 166 & $10.7-24.0$ & $12.4-171.2$ & 0.0035 & 3.4736 & 4.2884E-149 & $\mathrm{A}+$ \\
\hline \multirow[t]{2}{*}{ Jan-12 } & M & 243 & $10.6-22.6$ & $13.3-183.0$ & 0.0026 & 3.5921 & $1.8557 \mathrm{E}-221$ & $\mathrm{~A}+$ \\
\hline & $\mathrm{F}$ & 276 & $10.3-23.0$ & $12.0-186.1$ & 0.0027 & 3.5701 & 1.3832E-231 & $\mathrm{A}+$ \\
\hline \multirow[t]{2}{*}{ Feb } & M & 195 & $10.7-23.5$ & $13.9-225.2$ & 0.0026 & 3.5876 & $1.9981 \mathrm{E}-180$ & $\mathrm{~A}+$ \\
\hline & $\mathrm{F}$ & 134 & $11.5-23.9$ & $17.1-218.8$ & 0.0025 & 3.5865 & $3.38 \mathrm{E}-124$ & $\mathrm{~A}+$ \\
\hline
\end{tabular}

Note: M: Male; F: Female; n: number of measured specimens; a \& b: constant on regression; C: Cubic LW; A +: allometric positive; A-: allometric negative 
Table 2. Analysis of variance on the monthly value of Kn by sex

\begin{tabular}{|c|c|c|c|c|c|c|}
\hline $\begin{array}{c}\text { Source of variation } \\
\text { male }\end{array}$ & SS & df & MS & $\mathbf{F}$ & P-value & F crit \\
\hline Between groups & 3.7516 & 11 & 0.3411 & 22.4152 & $2.37 \mathrm{E}-43$ & 1.7941 \\
\hline Within groups & 26.5359 & 1744 & 0.0152 & & & \\
\hline Total & 30.2875 & 1755 & & & & \\
\hline \multicolumn{7}{|l|}{ Female } \\
\hline Between groups & 3.9563 & 11 & 0.3597 & 25.3124 & $2.973 \mathrm{E}-49$ & 1.7940 \\
\hline Within groups & 25.4055 & 1788 & 0.0142 & & & \\
\hline Total & 29.3617 & 1799 & & & & \\
\hline
\end{tabular}
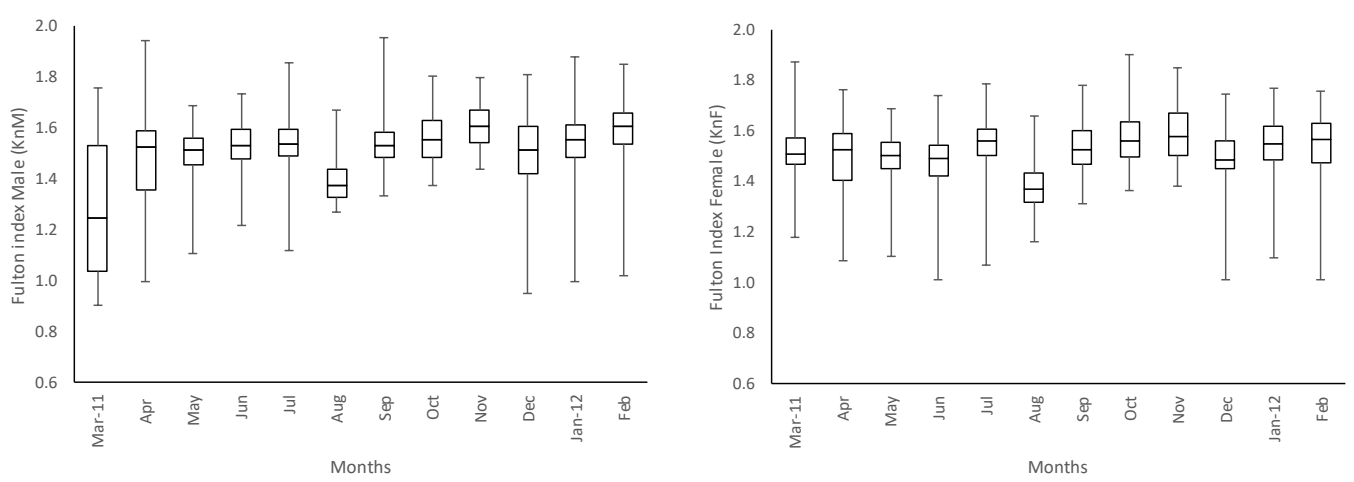

Figure 5. Monthly distribution of Fulton Index of Male (left) and Female (right)

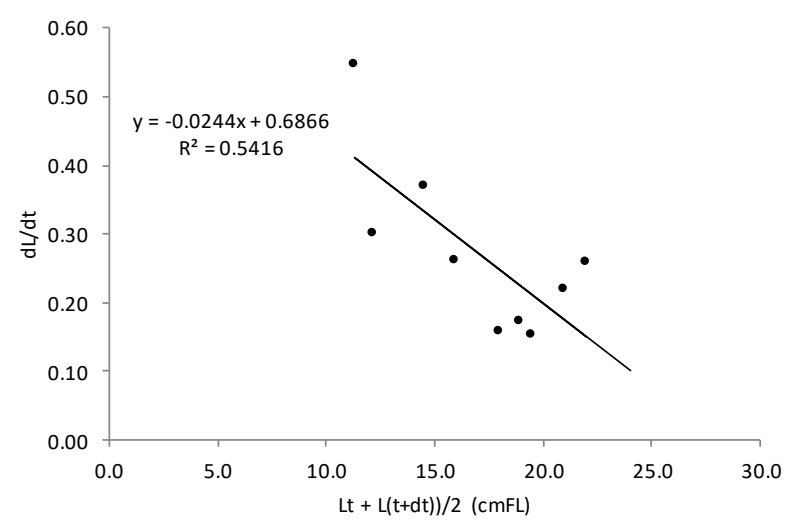

Figure 6. Scatter plot of ${ }^{\bar{L}}$ vs. dl/dt to estimate L $\infty$

Combining growth curve and estimated length at first maturity indicate that most of the catch was at mature and maturing size with an estimated age of more than 17 months (Figure 7). Previous findings on growth rates estimate in another area of Indonesia indicates that $\mathrm{K}$ values varied between 1.01-1.81 (Zamroni and Ernawati, 2019). This different probably due to different types of fisheries during sampling, which larger fish size (mature cohort) of sample occurred in this study compared with other previous findings that most of the sample was at an immature cohort.

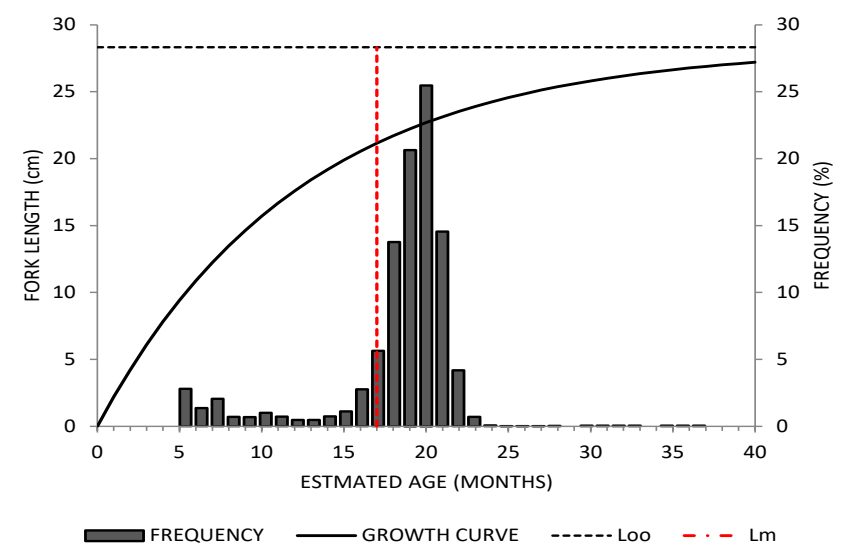

Figure 7. Growth curve and aggregated size distribution of catches.

A broader observation on the size distribution of $R$ kanagurta in different years within surrounding Raja Ampat indicates that the average size of fish caught by scoop net in Mayalibit bay on 2011, 2012, 2016, and 2017 ranging from $18.6-23.9 \mathrm{~cm}$ FL. The minimum and maximum sizes were relatively more significant than in 2011 and 2012. The size of specimens caught by mini purse seine and lift net was range from $14.0-27.0 \mathrm{~cm}$ and $11.0-15.0 \mathrm{~cm}$ respectively (Table 3 ). The different of average size by gear corresponds to their fishing tactic and strategy, including controllable access in Mayalibit bay, while open access with mini purse seine and lift net in the area beyond reserved areas. The frequency distribution by gear shown in Figure 8. 
Table 3. The size distribution of R. kanagurta surrounding Raja Ampat by type of fishing gears

\begin{tabular}{|c|c|c|c|c|c|c|c|c|}
\hline \multirow{2}{*}{ Year } & \multirow{2}{*}{ Month } & \multirow{2}{*}{ Area } & \multirow{2}{*}{ gear } & \multirow{2}{*}{ Specimens } & \multicolumn{3}{|c|}{ Length (cmFL) } & \multirow[t]{2}{*}{ Source } \\
\hline & & & & & Min & $\max$ & average & \\
\hline 2011 & Mar-Dec & Mayalibit & Scoop net & 2953 & 7.2 & 26.9 & $21.1+3.02$ & this study \\
\hline \multirow[t]{2}{*}{2012} & Jan-Feb & & & 1033 & 6.3 & 23.9 & $18.6+4.77$ & this study \\
\hline & Sep-Nov & Sorong & $\mathrm{mps}$ & 300 & 14.0 & 25.0 & $18.9 \pm 1.93$ & Suruwaki and Gunaisah (2013) \\
\hline 2014 & Jul-Sep & Ternate & mps & 1176 & 14.0 & 27.0 & $21.4+3.11$ & Tangke (2014) \\
\hline \multirow[t]{2}{*}{2016} & Jun & Mayalibit & Scoop net & 163 & 19.3 & 28.3 & $22.0+2.25$ & \\
\hline & & & Lift net & 62 & 11 & 15 & $12.7 \pm 1.08$ & This study \\
\hline 2017 & Jan-Feb & Mayalibit & & 442 & 20 & 27 & $23.9 \pm 1.21$ & Maskuri and Handayani, (2018) \\
\hline
\end{tabular}

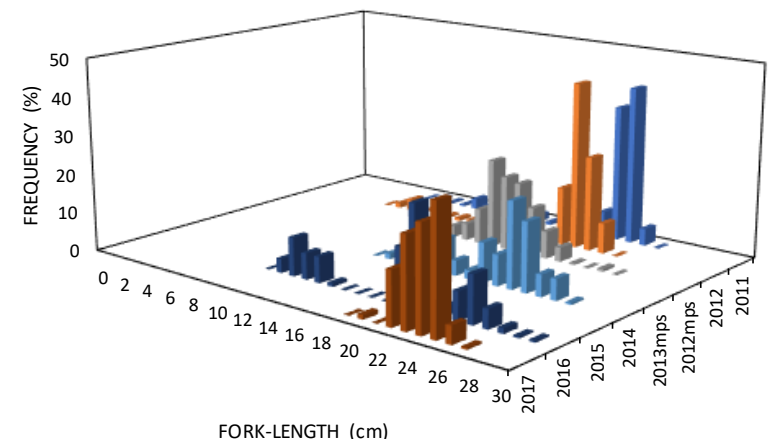

Figure 8. Semi-serial length-frequency caught by type of fisheries in Raja Ampat and its surrounding waters

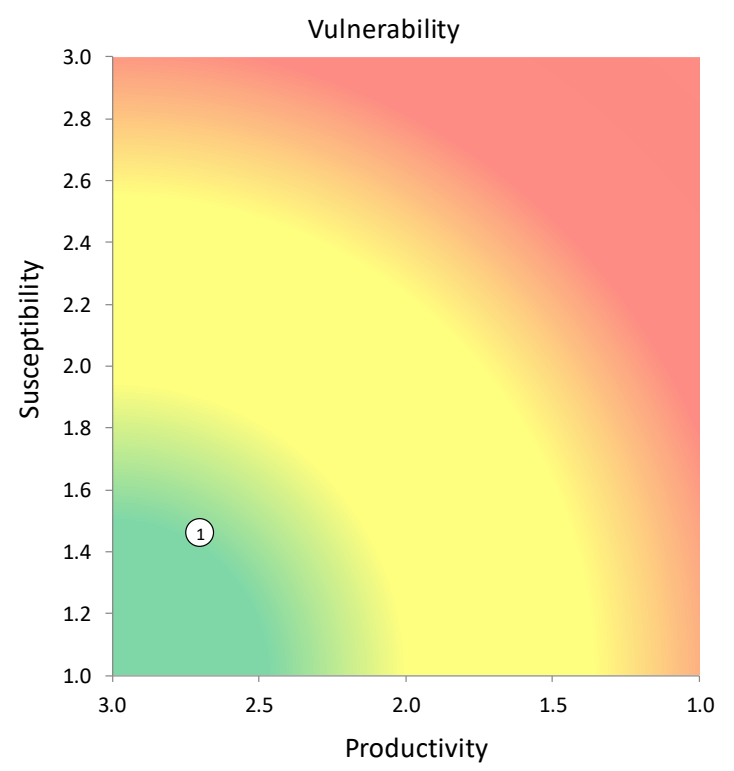

Figure 9. Productivity and susceptibility analysis of Rastrelliger kanagurta

\section{The bio-exploitation}

There is limited data available to predict the bioexploitation status of this species in the area of interest. A productivity-and-susceptibility analysis is one of the semiquantitative approaches that is commonly used in datalimited fisheries (Patrick et al. 2009; Rosenberg et al. 2009), such as in this study. Productivity indicates by aggregating biological sensitivity of the fish, i.e., age, maximum length, growth coefficient, natural mortality, measured fecundity, breeding strategy, and mean trophic level. Susceptibility indicators were estimated based on direct observation and some additional information that has been collected through interviews and desk studies. Parameters consisted of components that contribute to the disturbance of biomass productivity such as management strategy, areal overlaps, geographic concentration, vertical overlap. Other related parameters, i.e. Fishing rate $(\mathrm{F})$ relative to natural mortality $(\mathrm{M})$, estimate spawn biomass, seasonal migration, also schooling aggregation, morphology affecting capture, survival after capture, and release being considered. The desirable value of fisheries, fishery impact on habitat in general to non-targets were also included in this approach.

The capture fisheries statistics data showed that $R$. kanagurta is one of the targeted species by local community around Raja Ampat districts with the estimated annual landing ranged between 130 to 135 tons year ${ }^{1}{ }^{2}$ was harvested in 2010-2014 (BPS, Raja Ampat, 2016). Since the predictor of stock status is limited, insufficient data exist to perform its management measures. The relative data-poor stock through productivity and susceptibility analysis can be applied to support building indicators of status and trend of this particular species in the region. The productivity score was 2.7 , and the susceptibility 1.5 with vulnerability score at 0.6 . The score of data quality (Patrick et al. 2009) was relatively high. The productivity and susceptibility data quality score were at 1.50 and 1.33 , with an overall of 1.41 . The result indicates the vulnerability of $R$. kanagurta were at low risk or in relatively healthy condition (Figure 9).

This healthy utilization was also supported limited fishing regulation and declared by local village decree no.1/2013 on the code of conduct of lema fishery (Najamuddin et al. 2015). Local ecological knowledge was 
part of the activity of the existing fisheries in Warsambin and Lopintol village. The community agrees to comply with no fishing activities every Saturday and Sunday night during the peak season of laying eggs in the dark months, particularly in September, October, and November. Commitment to providing the opportunity of spawners to release their eggs, fishers also agree to avoid fishing every Saturday night throughout the year. The community aware on biology sensitivity of this primary fish resource by applying the idea of "We are aware of the importance of letting fish spawn, lay eggs and grow to ensure the availability of fish, protein sources and livelihoods for generations since the days of our ancestors," as part of belief of local community in Warsambin.

Increasing awareness of local government unit on simple best practice management strategy evaluation should be implemented. The regular monitoring program on catch and size data, including restricted technological creeps, should be fully complied by the community. This monitoring is suggested to support a series of data and information available since declaration on best practice of this type of fishing in 2013. Missing of series data could lead to uncertainty in management if this fish resource in a depletion status after years of exploitation.

\section{ACKNOWLEDGEMENTS}

Authors would thanks to Conservation International Indonesia (CI Indonesia) in Fiscal Year 2010/2011 and 2011/2012 and Research Institute for Marine Fisheries, Agency for Marine and Fisheries Research in Fiscal Year 2016 for their funding and facilitated during data collection. We also thank Andreas Samusamu for providing the map of Raja Ampat.

\section{REFERENCES}

Agostini VN, Grantham HS, Wilson J. Mangubhai S, Rotinsulu C, Hidayat N, Mulyadi A, Muhajir M, Mongdong M, Darmawan A, Rumetna L, Erdmann MV, Possingham HP. 2012. Achieving fisheries and conservation objectives within Marine Protected Areas: zoning the Raja Ampat Network. The Nature Conservancy, IndoPacific Division. Report No. 2/12. TNC, New York.

BPS (Statistics of Indonesia) 2018. Raja Ampat District in Figure. BPS Raja Ampat.

Collette BB, Nauen CE. 1983. FAO species 1983, catalog. Vol. 2. Scombrids of the world. An annotated and illustrated catalog of tunas, mackerels, bonitos and related species known to date. FAO Fish. Synop. 125 (2): 137 p.

Faizah R, Sadiyah L, Fauzi M. 2017. Population parameter and reproductive biology of Indian Mackerel (R. kanagurta Cuvier 1817) caught by lift net in Kwandang waters, North Gorontalo. Ind Fish Res J 23 (2): 107-115.

Fisher W, Whitehead PJP. Eds. 1974. FAO species identification sheets for fishery purposes. Eastern Indian Ocean (fishing area 57) and Western Central Pacific (fishing area 71). Volume 1. FAO, Rome.
Froese R. 2006. Cube law, condition factor, and weight-length relationships: history, meta-analysis, and recommendations. J Appl Ichthyol 22: 241-253. DOI: 10.1111/j.1439-0426.2006.00805.x

Froese R, Pauly D. (eds). 2000. Concepts, Design \& Data Sources. ICLARM, Los Banos, Laguna, Philippines.

Jin S, Yan S, Zhang H Fan W. 2015. Weight-length relationships and Fulton's condition factors of skipjack tuna (Katsuwonus pelamis) in the Western and Central Pacific Ocean. Peer J. DOI: $10.7717 /$ peerj. 758

King M, 2007. Fisheries Biology, Assessment, and Management. 2nd ed. Blackwell Publishing Oxford, UK.

Maskuri A, Handayani T. 2018. Distribution of size and production of fish (Rastreliger sp.) fishing products in Kampung Warsambin Teluk Mayalibit District, Raja Ampat District, Papua Barat. Pros. Seminar Nasional MIPA UNIPA III. 135-147.

McKenna SA, Allen GR, Suryadi S (eds). 2002. A Marine rapid assessment of the Raja Ampat Islands, Papua Province, Indonesia. RAP Bulleting of Biological Assessment 22. Conservation International, Washington DC.

Najamuddin W, Reppie E, Manoppo L. 2015. Management of mackerel (Rastrelliger kanagurta) resources based on local wisdom in the village of Warsambin and Lopintol, Mayalibit Bay District, Province of West Papua. J Ilmu dan Teknologi Perikanan Tangkap 2 (1): 28 32.

Nair PG, Joseph S, Pilai VN. 2015. Length-weight relationship and relative condition factor of Stolephorus commersonii (Lacepede, 1803) exploited along the Kerala coast. J Mar Biol Ass India 57 (2): 27-31.

Oktaviani D. 2014. Ethnozoology, Reproductive Biology, and Sustainable Use of Indian Mackerel Rastrelliger kanagurta (Cuvier, 1816) in Mayalibit Bay Raja Ampat Regency, West Papua, Indonesia. [Dissertation]. Universitas Indonesia, Depok. [Indonesian].

Oktaviani D, Baroto EB, Supriatna J, Erdman M. 2012. Ethnoichthyology of Ikan Lema (Rastrelliger spp.). in Mayalibit Bay, Raja Ampat District, West Papua. Seminar Nasional Tahunan IX Hasil Penelitian Perikanan dan Kelautan, UGM. 14 Juli 2012. 11 p. [Indonesian]

Oktaviani D, Supriatna J, Erdmann M, Abinawanto A. 2014. Maturity Stages of Indian Mackerel Rastrelliger kanagurta (Cuvier, 1817) In Mayalibit Bay, Raja Ampat, West Papua. Intl J Aquat Sci 5 (1): 67 76.

Oktaviani D, Matatar B, Nugroho D. 2015. The occurrence of translucent ovaries as an indicator of peak Spawning season of Indian mackerel Rastrelliger kanagurta (Cuvier, 1816) In Mayalibit bay Raja Ampat islands. BAWAL 7 (1): 21-57.

Patrick WS, Spencer P, Ormseth O, Cope J, Field J, Kobayashi D, Gedamke T, Cortés E, Bigelow K, Overholtz W, Link J, Lawson P. 2009. Use of productivity and susceptibility indices to determine stock vulnerability, with example applications to six U.S. fisheries. U.S. Dep. Commer., NOAA Tech. Memo. NMFS-F/SPO-101, 90 p.

Petrakis G, Stergiou KI. 1995. Weight-length relationships for 33 fish species in Greek waters. Fish. Res., 21: 465-469. DOI: 10.1016/01657836 (94)00294-7

Rosenberg AA, Acosta A, Babcock E, Harrington J, Hobday A, Mogensen CB, O’Boyle R, Rader D, Swasey JH, Trumble RJ, Wakeford RC. 2009. Use of Productivity-Susceptibility Analysis (PSA) in Setting Annual Catch Limits for U.S. Fisheries: A Workshop Report. 21 p.

Stevenson RD, Woods WA. 2006. Condition indices for conservation: new uses for evolving tools. Intgr Comp Biol 46 (6): 1169-1190. DOI:10.1093/icb/icl052

Suruwaki AM, Gunaisah E. 2013. Length-weight relationships as identification of exploitation level of Indian mackerel (Rastrelliger kanagurta). J. Akuatika 8 (2): 131-140.

Tangke U. 2014. Monitoring of population dynamics of Indian mackerel (Rastrelliger spp) in coastal waters of Ternate, North Moluccas. J. Ilmiah Agribisnis dan Perikanan. 7 (2): 8-14. DOI: 10.29239/j.agrikan.12.2

UU No. 7/2016 on Fisher protection, fish, and salt farmers. [Indonesian]. 